\title{
Kombinasi Metode Partial Least Square (PLS) dan Technology Acceptance Model (TAM) : Evaluasi Pembelajaran (Praktikum Online)
}

\author{
Nariza Wanti Wulan Sari ${ }^{1 *}$, Ika Purnamasari ${ }^{2}$ Fahrullah $^{3}$ \\ ${ }^{1,3}$ Program Studi Sistem Informasi, Fakultas Ilmu Komputer, Universitas Mulia, \\ ${ }^{2}$ Program Studi Statistika, Fakultas Matematika dan Ilmu Pengetahun Alam, Universitas Mulawarman \\ *nariza.ws@universitasmulia.ac.id
}

\begin{abstract}
Corona virus disease (Covid-19) pandemic give effect in education. During the pandemic, the learning process was done online both of theory and practicum based on the e-learning system. Combination of partial least square (PLS) method and technology acceptance model (TAM) method used to evaluate the learning process to know students' understanding especially practicum online. Variables using in TAM are perceived ease of use, perceived usefulness, attitude toward using, and behavioral intention. The results of this research show that there is a positive attitude by students who feel easy to do the online practicum. However, this not affects their enthusiasm to do online practicum again.
\end{abstract}

Key words: Covid-19, PLS, TAM

\begin{abstract}
Abstrak
Pandemi Corona virus disease (Covid-19) memberikan dampak bagi dunia pendidikan. Selama pandemik pembelajaran baik teori maupun praktikum dilakukan secara online berbasis $e$-learning. Evaluasi pembelajaran terkait pemahaman mahasiswa khususnya kuliah praktikum online dapat dilakukan dengan menggunakan kombinasi metode partial least square (PLS) dan metode technology acceptance model (TAM). Variabel yang digunakan dalam TAM yaitu perceived ease of use, perceived usefulness, attitude toward using, dan behavioral intention. Hasil penelitian menunjukkan adanya sikap positif mahasiswa yang merasa mudah melaksanakan kuliah praktikum online. Namun, sikap positif tersebut tidak mempengaruhi keinginian mahasiswa untuk terus melaksanakan praktikum secara online.
\end{abstract}

Kata kunci: Covid-19, PLS, TAM

\section{Pendahuluan}

Corona virus disease (Covid-19) merupakan salah satu virus yang membuat pandemi secara global. Data World Health Organization (WHO) menyatakan bahwa sebanyak 216 negara, area, dan wilayah tercatat memiliki kasus Covid-19 salah satunya yaitu Indonesia. Pandemi Covid-19 telah mengubah pola tatanan kehidupan masyarakat di segala bidang tak terkecuali bidang pendidikan.

Menteri Pendidikan dan Kebudayaan Republik Indonsia mengeluarkan Surat Nomor 36962/MPK.A/HK/2020 mengenai pembelajaran secara daring dan bekerja dari rumah dalam rangka pencegahan penyebaran Corona virus disease (Covid-19). Hal ini merupakan tuntutan sekaligus dorongan bagi dosen dan mahasiwa untuk melakukan proses pembelajaran secara daring (online) yang lebih dikenal dengan E-learning. E-learning merupakan satu sistem atau konsep dasar pembelajaran dengan memanfaatkan kecanggihan teknologi dalam proses belajar mengajar baik teori maupun praktik tanpa harus adanya tatap muka secara langsung, sebagaimana protokol pencegahan Covid-19. [1]-[3]

Berbasis e-learning sistem, pemahaman mahasiswa terhadap pembelajaran terutama 
kuliah praktikum dapat diukur dengan menggunakan metode Technology Acceptance Model (TAM). Metode TAM dapat diaplikasikan dibidang ekonomi dan bisnis, teknologi, kesehatan, maupun pendidikan[4]-[6] . TAM memiliki tujuan utama yaitu mengukur sejauh mana pemahaman dari objek individu dalam menggunakan perangkat komputer secara umum [7] dalam [8]. Tujuan penelitian ini adalah untuk mengetahui pemahaman mahasiswa terhadap kuliah praktikum secara online pada Program Studi Sistem Informasi dan Diploma Manajemen Informatika di Universitas Mulia Kampus Samarinda.

\section{Metoda Penelitian}

Populasi dalam penelitian ini adalah semua mahasiswa Universitas Mulia Kampus Samarinda yang mengikuti kuliah praktikum online semester genap tahun ajaran 2019/2020 yang terbagi dalam 2 (dua) program studi. Data populasi diperoleh melalui Biro Administrasi Akademik Kemahasiswaan yang berjumlah 188 mahasiswa. Metode sampling yang digunakan adalah convenience sampling, hal ini untuk mempermudah peneliti mendapatkan sampel. Sampel yang diperoleh sebanyak 65 responden atau 34,6\% dari jumlah total populasi. [9]

Metode pengumpulan data menggunakan kuesioner yang diisi oleh responden melalui Google Form. Skala pengukuran jawaban responden yang digunakan adalah skala likert. Skala likert yang digunakan memiliki 5 pilihan jawaban pada setiap butir pernyataan, dari sangat tidak setuju hingga sangat setuju. [10]

Berdasarkan technology acceptance model yang telah disesuaikan pada penelitian ini seperti yang ditunjukkan pada Gambar 1 variabel yang digunakan adalah perceived ease of use, perceived usefulness, attitude toward using, dan behavioral intention. Perceived ease of use (persepsi kemudahan) menggambarkan tingkat kepercayaan responden untuk kuliah praktikum online bahwa merupakan hal yang mudah dan tidak memerlukan usaha yang keras. Perceived usefulness (persepsi manfaat) merupakan refleksi perasaan atas kuliah praktikum online dalam kondisi baik atau buruk, menguntungkan atau merugikan. Attitude toward using (sikap penggunaan) merupakan sikap positif maupun negatif setiap responden terhadap kuliah praktikum online dan behavioral intention (minat berperilaku) merupakan keinginan responden untuk berperilaku menurut cara tertentu dalam rangka menggunakan produk atau jasa dalam hal ini kuliah praktikum online. [11]-[12]

Konstruk dan indikator dapat dilihat pada Tabel 1.

Tabel 1. Konstruk dan Indikator

\begin{tabular}{|c|c|c|}
\hline Konstruk & & Indikator \\
\hline \multirow{4}{*}{$\begin{array}{l}\text { Perceived } \\
\text { Ease of Use }\end{array}$} & $\mathrm{X} 1.1$ & Kemudahan dipelajari \\
\hline & $\mathrm{X} 1.2$ & Mudah dipahami \\
\hline & $\mathrm{X} 1.3$ & Mudah diakses \\
\hline & $\mathrm{X} 1.4$ & Mudah digunakan \\
\hline \multirow{4}{*}{$\begin{array}{l}\text { Perceived } \\
\text { Usefulness }\end{array}$} & $\mathrm{X} 2.1$ & $\begin{array}{l}\text { Lebih mudah } \\
\text { Meningkatkan } \\
\text { produktivitas }\end{array}$ \\
\hline & $\mathrm{X} 2.3$ & Meningkatkan efektifitas \\
\hline & $\mathrm{X} 2.4$ & Meningkatkan kinerja \\
\hline & $\mathrm{X} 2.5$ & Bermanfaat \\
\hline \multirow{3}{*}{$\begin{array}{l}\text { Attitude } \\
\text { Toward } \\
\text { Using }\end{array}$} & $\mathrm{X} 3.1$ & Rasa senang \\
\hline & $\mathrm{X} 3.2$ & Menikmati \\
\hline & $\mathrm{X} 3.3$ & Tidak suka \\
\hline \multirow{3}{*}{$\begin{array}{l}\text { Behavioral } \\
\text { Intention }\end{array}$} & $\mathrm{X} 3.4$ & $\begin{array}{l}\text { Tidak puas } \\
\text { Menggunakan online } \\
\text { dibandingkan tatap muka }\end{array}$ \\
\hline & Y.2 & Terus menggunakan \\
\hline & Y.3 & Motivasi \\
\hline
\end{tabular}

Model penelitian dalam penelitian ini merujuk kepada [13] tanpa menggunakan variabel eksternal seperti yang ditunjukkan pada Gambar 1.

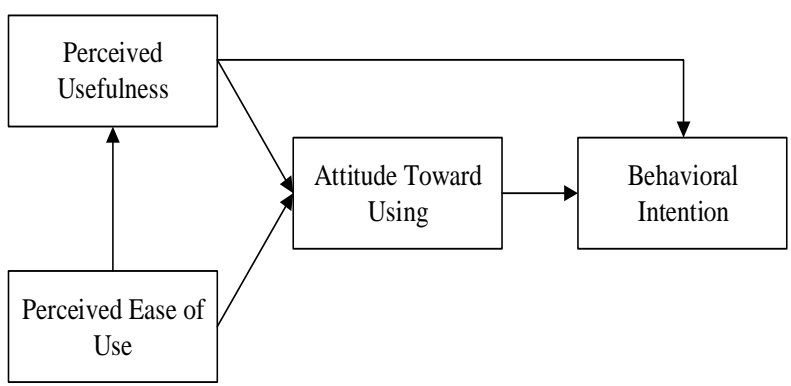

Gambar 1. Model Penelitian

Model penelitian ini menggambarkan hubungan yang dihipotesiskan antara 
konstruk yang merupakan faktor penentu penerimaan mahasiswa terhadap kuliah praktikum online. Berdasarkan hasil tinjauan literatur dan penelitian sebelumnya, maka hipotesis yang digunakan dalam penelitian ini sebagai berikut:

H1: Perceivedease of use berpengaruh terhadap perceived usefulness

H2: Perceivedease of use berpengaruh terhadap attitude toward using

H3: Perceivedusefulness berpengaruh terhadap attitude toward using

H4: Perceivedusefulness berpengaruh terhadap behavioral intention

H5: Attitude toward using berpengaruh terhadap behavioral intention

Analisis data yang digunakan pada penelitian ini adalah Structural Equation Model yang berbasis varians yaitu Partial Least Square (PLS). Analisis SEM dengan PLS terdiri dari dua sub model yaitu model pengukuran (measurement model) atau sering disebut outer model dan model struktural (structural model) atau sering disebut inner model. Model pengukuran menunjukkan bagaimana variabel manifest atau observed variabel mempresentasikan variabel laten untuk diukur. Sedangkan model struktural menunjukkan kekuatan estimasi antar variabel laten atau konstruk. [14]

\section{Hasil Penelitian}

\subsection{Karakteristik responden dan Jawaban Responden}

Karakteristik responden yang digambarkan yakni jenis kelamin dan usia responden. Sebanyak $84 \%$ atau 56 responden berjenis kelamin laki-laki dan sisanya $14 \%$ atau 9 orang perempuan.

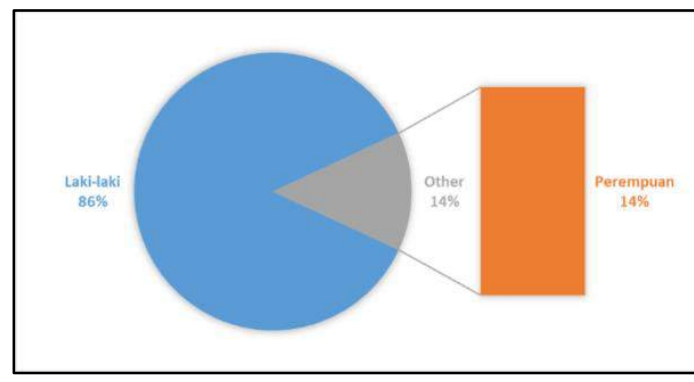

Gambar 2. Karakteristik Jenis Kelamin

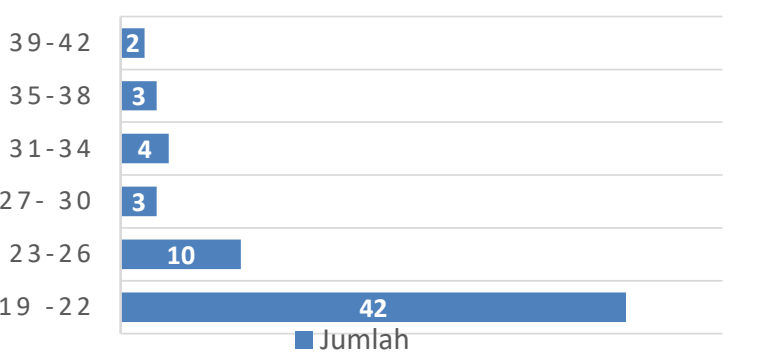

Gambar 3. Karakteristik Usia

Responden termuda berusia 19 tahun dan paling tua berusia 42 tahun. Sebagian besar responden berusia antara 19 sampai 22 tahun.

Berdasarkan deskripsi jawaban responden pada Tabel 2 diperoleh bahwa ratarata $62.21 \%$ responden menjawab setuju dan sangat setuju dan $37.82 \%$ menjawab sangat tidak setuju dan setuju. Hal ini berarti respon mahasiswa terhadap praktikum kuliah secara online sebagian besar baik.

Tabel 2. Deskripsi Jawaban Responden

\begin{tabular}{|c|c|c|c|c|}
\hline \multirow[b]{2}{*}{ Indikator } & \multicolumn{4}{|c|}{ Frekuensi Jawaban Responden } \\
\hline & $\begin{array}{l}\text { Sangat } \\
\text { Tidak } \\
\text { Setuju }\end{array}$ & $\begin{array}{l}\text { Tidak } \\
\text { Setuju }\end{array}$ & Setuju & $\begin{array}{l}\text { Sangat } \\
\text { Setuju }\end{array}$ \\
\hline $\begin{array}{l}\text { Kemudahan } \\
\text { dipelajari }\end{array}$ & $10.80 \%$ & $15.40 \%$ & $55.30 \%$ & $18.50 \%$ \\
\hline $\begin{array}{l}\text { Mudah } \\
\text { dipahami }\end{array}$ & $6.20 \%$ & $21.50 \%$ & $49.20 \%$ & $23.10 \%$ \\
\hline $\begin{array}{l}\text { Mudah } \\
\text { diakses }\end{array}$ & $7.70 \%$ & $9.20 \%$ & $44.60 \%$ & $38.50 \%$ \\
\hline $\begin{array}{l}\text { Mudah } \\
\text { digunakan }\end{array}$ & $4.60 \%$ & $10.80 \%$ & $60.00 \%$ & $24.60 \%$ \\
\hline Lebih mudah & $12.30 \%$ & $18.50 \%$ & $38.50 \%$ & $30.80 \%$ \\
\hline $\begin{array}{l}\text { Meningkatkan } \\
\text { produktivitas }\end{array}$ & $15.40 \%$ & $29.40 \%$ & $43.10 \%$ & $12.30 \%$ \\
\hline $\begin{array}{l}\text { Meningkatkan } \\
\text { efektifitas }\end{array}$ & $15.40 \%$ & $27.70 \%$ & $43.10 \%$ & $13.80 \%$ \\
\hline $\begin{array}{l}\text { Meningkatkan } \\
\text { kinerja }\end{array}$ & $9.20 \%$ & $43.10 \%$ & $35.40 \%$ & $12.30 \%$ \\
\hline Bermanfaat & $9.20 \%$ & $29.30 \%$ & $33.80 \%$ & $27.70 \%$ \\
\hline Rasa senang & $10.80 \%$ & $24.60 \%$ & $40.00 \%$ & $24.60 \%$ \\
\hline Menikmati & $10.80 \%$ & $26.20 \%$ & $43.10 \%$ & $20.00 \%$ \\
\hline Suka & $23.10 \%$ & $23.10 \%$ & $36.90 \%$ & $16.90 \%$ \\
\hline Puas & $9.20 \%$ & $30.80 \%$ & $32.30 \%$ & $27.70 \%$ \\
\hline $\begin{array}{l}\text { Menggunakan } \\
\text { e-learning } \\
\text { dibandingkan } \\
\text { tatap muka }\end{array}$ & $18.50 \%$ & $35.40 \%$ & $27.70 \%$ & $18.50 \%$ \\
\hline $\begin{array}{l}\text { Terus } \\
\text { menggunakan }\end{array}$ & $15.40 \%$ & $36.90 \%$ & $29.20 \%$ & $18.50 \%$ \\
\hline Motivasi & $12.30 \%$ & $32.30 \%$ & $40.00 \%$ & $15.40 \%$ \\
\hline Rata-rata & $11.93 \%$ & $25.89 \%$ & $40.76 \%$ & $21.45 \%$ \\
\hline
\end{tabular}




\subsection{Evaluasi Model Pengukuran}

Evaluasi model pengukuran (outer model) terdiri dari beberapa tahap yaitu uji validitas konvergen, uji validitas diskriminan, dan uji reliabilitas. Pengujian validitas konvergen untuk indikator reflektif dapat dilihat dari nilai loading factor untuk tiap indikator konstruk, nilai loading factor harus lebih dari 0.7 dan AVE harus lebih dari 0.5. Tabel 3 menunjukan nilai loading factor untuk tiap indikator konstruk.[14]

\begin{tabular}{ccc}
\multicolumn{3}{c}{ Tabel 3. Loading Factor } \\
\hline Konstruk & Indikator & $\begin{array}{c}\text { Outer } \\
\text { Loading }\end{array}$ \\
\hline Perceived Ease of & $\mathrm{X} 1.1$ & 0.889 \\
Use & $\mathrm{X} 1.3$ & 0.875 \\
& $\mathrm{X} 1.4$ & 0.728 \\
& $\mathrm{X} 2.1$ & 0.858 \\
Perceived & $\mathrm{X} 2.2$ & 0.880 \\
Usefulness & $\mathrm{X} 2.3$ & 0.923 \\
& $\mathrm{X} 2.4$ & 0.882 \\
& $\mathrm{X} 2.5$ & 0.894 \\
& $\mathrm{X} 3.1$ & 0.900 \\
Attitude Toward & $\mathrm{X} 3.2$ & 0.929 \\
Using & $\mathrm{X} 3.3$ & 0.702 \\
& $\mathrm{X} 3.4$ & 0.727 \\
Behavioral & $\mathrm{Y} .1$ & 0.875 \\
Intention & $\mathrm{Y} .2$ & 0.938 \\
& $\mathrm{Y} .3$ & 0.901 \\
\hline
\end{tabular}

Berdasarkan Tabel 3 diketahui untuk semua indikator konstruk memiliki nilai nilai loading factor lebih dari 0.7 dan pada Tabel 4 diperoleh nilai AVE lebih dari 0.5 maka dapat disimpulkan bahwa semua indikator konstruk telah memenuhi validitas konvergen.

\begin{tabular}{cc}
\multicolumn{2}{c}{ Tabel 4. AVE } \\
\hline Konstruk & $\begin{array}{c}\text { Average Variance } \\
\text { Extracted (AVE) }\end{array}$ \\
\hline Perceived Ease of Use & 0.819 \\
Perceived Usefulness & 0.788 \\
Attitude Toward Using & 0.674 \\
Behavioral Intention & 0.656 \\
\hline
\end{tabular}

Validitas diskriminan berhubungan dengan prinsip bahwa pengukur-pengukur (manifest variable) konstruk yang berbeda seharusnya tidak berkorelasi dengan tinggi.

Pengujian validitas diskriminan dengan melihat nilai cross loading untuk setiap variabel harus > 0.70. Menurut Alfa, Rachmatin, dan Agustina (2017) suatu indikator dinyatakan valid jika mempunyai loading factor tertinggi kepada konstruk yang dituju dibandingkan nilai loading factor kepada konstruk lain.[14][15]

\begin{tabular}{ccccc}
\multicolumn{5}{c}{ Tabel 5. Validitas Diskriminan } \\
\hline Indika & $\begin{array}{c}\text { Attitude } \\
\text { Toward } \\
\text { tor }\end{array}$ & $\begin{array}{c}\text { Behaviora } \\
\text { Using }\end{array}$ & $\begin{array}{c}\text { Perceive } \\
\text { d Ease of } \\
\text { Use }\end{array}$ & $\begin{array}{c}\text { Perceived } \\
\text { Usefulness }\end{array}$ \\
\hline X1.1 & 0.710 & 0.651 & 0.889 & 0.812 \\
X1.2 & 0.582 & 0.593 & 0.875 & 0.727 \\
X1.3 & 0.439 & 0.337 & 0.728 & 0.506 \\
X1.4 & 0.421 & 0.397 & 0.734 & 0.411 \\
X2.1 & 0.718 & 0.695 & 0.716 & 0.858 \\
X2.2 & 0.726 & 0.738 & 0.679 & 0.880 \\
X2.3 & 0.694 & 0.698 & 0.684 & 0.923 \\
X2.4 & 0.624 & 0.731 & 0.738 & 0.882 \\
X2.5 & 0.759 & 0.676 & 0.698 & 0.894 \\
X3.1 & 0.900 & 0.734 & 0.690 & 0.809 \\
X3.2 & 0.929 & 0.728 & 0.666 & 0.780 \\
X3.3 & 0.702 & 0.319 & 0.396 & 0.357 \\
X3.4 & 0.727 & 0.383 & 0.395 & 0.500 \\
Y.1 & 0.586 & 0.875 & 0.480 & 0.663 \\
Y.2 & 0.711 & 0.938 & 0.581 & 0.747 \\
Y.3 & 0.630 & 0.901 & 0.657 & 0.751 \\
\hline & & & &
\end{tabular}

Tabel 5 menunjukkan bahwa nilai cross loading untuk setiap variabel $>0,70$ dan untuk setiap konstruk yang dituju mempunyai loading factor tertinggi, sehingga disimpulkan bahwa telah memenuhi validitas diskriminan.

Untuk mengukur reliabilitas suatu konstruk dengan indikator refleksif dapat dilakukan dengan dua cara yaitu dengan Cronbach's Alpha dan composite relibility sering disebut Dillon-Goldstein. Pengujiian reliabilitas dengan Cronbach's Alpha dan composite relibility harus lebih besar dari 0.7 . [14]

Tabel 6. Hasil Uji Reliabilitas

\begin{tabular}{lcc}
\hline Konstruk & $\begin{array}{l}\text { Cronbach's } \\
\text { Alpha }\end{array}$ & $\begin{array}{c}\text { Composite } \\
\text { Reliability }\end{array}$ \\
\hline Perceived Ease of Use & 0.889 & 0.931 \\
Perceived Usefulness & 0.933 & 0.949 \\
Attitude Toward Using & 0.846 & 0.891 \\
Behavioral Intention & 0.828 & 0.883 \\
\hline
\end{tabular}


Hasil pengujian reliabilitas ditunjukkan pada Tabel 6 diperoleh bahwa untuk semua konstruk memiliki nilai Cronbach's Alpha dan composite relibility lebih besar dari 0.7. Sehingga disimpulkan semua konstruk telah reliabel.

\subsection{Evaluasi Model Struktural}

Evaluasi model struktural (inner model) terdiri dari $R$-square dan uji signifikansi melalui estimasi koefisien jalur. Perubahan nilai $R$-Square digunakan untuk menjelaskan pengaruh variabel laten eksogen tertentu terhadap variabel laten endogen apakah mempunyai pengaruh yang substantive. Nilai $R$-Square $0.75, \quad 0.5$, dan 0.25 dapat disimpulkan bahwa model kuat, moderate, dan lemah. [14][16]

Tabel 7. Nilai R-Square

\begin{tabular}{lc}
\hline \multicolumn{1}{c}{ Konstruk } & $R$-Square \\
\hline Perceived Usefulness & 0.628 \\
Attitude Toward Using & 0.640 \\
Behavioral Intention & 0.653 \\
\hline
\end{tabular}

Hasil pada Tabel 7 menunjukkan bahwa nilai R-Square lebih besar dari 0.5 maka dikategorikan sebagai moderate.

Tabel 8. Path Coeficient

\begin{tabular}{cccc}
\hline Indikator & $\begin{array}{c}\text { Original } \\
\text { Sampel } \\
\text { Estimate }\end{array}$ & $\begin{array}{c}T \text { - } \\
\text { Statistics }\end{array}$ & P.Value \\
\hline $\begin{array}{c}\text { Perceived Ease } \\
\text { of Use -> } \\
\text { Perceived }\end{array}$ & 0.792 & 20.978 & 0 \\
$\begin{array}{c}\text { Usefulness } \\
\text { Perceived Ease } \\
\text { of Use -> }\end{array}$ & 0.154 & 1.721 & 0.086 \\
$\begin{array}{c}\text { Attitude Toward } \\
\text { Using }\end{array}$ & & & \\
$\begin{array}{c}\text { Perceived } \\
\text { Usefulness -> }\end{array}$ & 0.672 & 7.101 & 0 \\
$\begin{array}{c}\text { Attitude Toward } \\
\text { Using }\end{array}$ & & & \\
$\begin{array}{c}\text { Perceived } \\
\text { Usefulness -> } \\
\text { Behavioral } \\
\text { Intention }\end{array}$ & 0.629 & 4.483 & 0 \\
Attitude Toward \\
$\begin{array}{c}\text { Using -> } \\
\text { Behavioral } \\
\text { Intention }\end{array}$ & 0.212 & 1.397 & 0.163 \\
\hline
\end{tabular}

Menggunakan hipotesis $\mathrm{H}_{0}$ : variabel $\mathrm{X}_{\mathrm{i}}$ tidak berpengaruh terhadap variabel $\mathrm{Y}_{\mathrm{j}}$, dimana $i \neq j$. Taraf signifikansi $(\alpha)$ sebesar $5 \%$ dan $\mathrm{H}_{0}$ ditolak jika T-Statistics $>1.96$ atau
P.Value $<0.05$. Berdasarkan Tabel 8 maka dapat disimpulkan sebagai berikut.[14]

a. Pengujian hipotesi perceived ease of use berpengaruh terhadap perceived usefulness

Pada Tabel 8 diperoleh $T$-Statistics $=$ $20.978>1.96$ dan P.Value $=0<0.05$, maka Ho ditolak sehingga disimpulkan bahwa perceived ease of use berpengaruh terhadap perceived usefulness. Pada original sample estimate diperoleh nilai 0.729 menunjukkan arah hubungan perceived ease of use terhadap perceived usefulness positif. Hal ini sesuai dengan penelitian [13], mengindikasikan bahwa ketika mahasiswa merasakan kemudahan pada kuliah praktikum online maka kegunaan yang dirasakan juga meningkat.

b. Pengujian hipotesis perceived ease of use berpengaruh terhadap attitude toward using

Pada Tabel 8 diperoleh $T$-Statistics $=$ $1.721<1.96$ dan $P$.Value $=0.086>0.05$, maka Ho gagal ditolak sehingga disimpulkan bahwa perceived usefulness tidak berpengaruh terhadap attitude toward using. Kuliah praktikum online yang dirasakan mudah oleh mahasiswa namun tidak mengembangkan sikap positif terhadap penggunaannya.

c. Pengujian hipotesis perceived usefulness berpengaruh terhadap attitude toward using

Pada Tabel 8 diperoleh $T$-Statistics $=$ $7.101>1.96$ dan P.Value $=0<0.05$, maka Ho ditolak sehingga disimpulkan bahwa perceivedusefulness berpengaruh terhadap attitude toward using. Pada original sample estimate diperoleh nilai 0.672 menunjukkan arah hubungan perceived usefulness terhadap attitude toward using positif. Kegunaan meningkatkan sikap positif terhadap penggunaannya.

d. Pengujian hipotesis perceived usefulness berpengaruh terhadap behavioral intention

Pada Tabel 8 diperoleh $T$-Statistics $=$ $4.483>1.96$ dan P.Value $=0<0.05$, maka Ho ditolak sehingga disimpulkan bahwa perceived usefulness berpengaruh 
terhadap behavioral intention. Pada original sample estimate diperoleh nilai 0.212 menunjukkan arah hubungan perceived usefulness terhadap behavioral intention positif. Kegunaan dari kuliah praktikum online yang dirasakan mahasiswa meningkatkan perilaku untuk menggunakan.

e. Pengujian hipotesis attitude toward using berpengaruh terhadap behavioral intention

Pada Tabel 8 diperoleh T-Statistics = $1.397>1.96$ dan P.Value $=0<0.05$, maka Ho gagal ditolak sehingga disimpulkan bahwa attitude toward using tidak berpengaruh terhadap behavioral intention. Sikap positif terhadap pemanfaatan kuliah praktikum secara online tidak mempengaruhi keinginan mahasiswa untuk menggunakan kuliah praktikum online.

\section{Kesimpulan}

Pada penelitian ini diketahui berdasarkan hasil jawaban responden disimpulkan bahwa respon mahasiswa terhadap kuliah praktikum secara online sebagian besar baik. Kesimpulan yang diperoleh berdasarkan hipotesis yaitu ketika mahasiswa merasakan kemudahan pada kuliah praktikum online maka kegunaan yang dirasakan juga meningkat, kuliah praktikum online yang dirasakan mudah oleh mahasiswa namun tidak mengembangkan sikap positif terhadap penggunaannya, kegunaan meningkatkan sikap positif terhadap penggunaannya, kegunaan dari kuliah praktikum online yang dirasakan mahasiswa meningkatkan perilaku untuk menggunakan, dan sikap positif terhadap pemanfaatan kuliah praktikum secara online tidak mempengaruhi keinginan mahasiswa untuk menggunakan kuliah praktikum online.

Secara keseluruhan bahwa kuliah praktikum online mudah dilaksanakan, bermanfaat, dan mendapat sambutan yang positif bagi mahasiswa. Namun sebagian besar masih memilih untuk melaksanakan praktikum secara tatap muka. Berdasarkan masukan yang diberikan responden, hal ini terkait masalah koneksi internet yang kurang baik dan waktu kuliah yang diperingkas.

\section{Daftar Pustaka}

[1] S. R. Chandrawati, 'Pemamfaatan ELearning Dalam Pembelajaran', P. 10.

[2] S. Muzid And M. Munir, 'Persepsi Mahasiswa Dalam Penerapan E-Learning Sebagai Aplikasi Peningkatan Kualitas Pendidikan (Studi Kasus Pada Universitas Islam Indonesia)', P. 8, 2005.

[3] E. Susanti And M. Sholeh, 'Rancang Bangun Aplikasi E-Learning', Jurnal Teknologi, Vol. 1, No. 1, P. 5.

[4] D. Kurniawan And J. Siwalankerto, 'Analisis Penerimaan Nasabah Terhadap Layanan Mobile Banking Dengan Menggunakan Pendekatan Technology Acceptance Model Dan Theory Of Reasoned Action', Vol. 1, No. 1, P. 13, 2013.

[5] R. Aditya And A. Wardhana, 'Pengaruh Perceived Usefulness Dan Perceived Ease Of Use Terhadap Behavioral Intention Dengan Pendekatan Technology Acceptance Model (Tam) Pada Pengguna Instant Messaging Line Di Indonesia', $J_{s} b$, Vol. 20, No. 1, Pp. 24-32, Jan. 2016, Doi: 10.20885/Jsb.Vol20.Iss1.Art3.

[6] B. Satya And R. Aditya, 'Analisis Penerimaan (Acceptance) Penerapan Internet Sehat Dengan Technology Acceptance Model (Tam) (Studi Kasus Pada Stmik Amikom Yogyakarta)', Vol. 14, No. 1, P. 4, 2013.

[7] F. D. Davis, 'Perceived Usefulness, Perceived Ease Of Use, And User Acceptance Of Information Technology', Mis Quarterly, Vol. 13, No. 3, P. 319, Sep. 1989, Doi: 10.2307/249008.

[8] F. Sayekti And P. Putarta, 'Penerapan Technology Acceptance Model (Tam) Dalam Pengujian Model Penerimaan Sistem Informasi Keuangan Daerah', No. 3, P. 14, 2016.

[9] H. Taherdoost, 'Sampling Methods In Research Methodology; How To Choose A Sampling Technique For Research', Ssrn Electronic Journal, No. September, 2018, Doi: 10.2139/Ssrn.3205035.

[10] W. Budiaji, 'Skala Pengukuran Dan Jumlah Respon Skala Likert (The Measurement Scale And The Number Of Responses In Likert Scale)', Ilmu Pertanian Dan Perikanan, Vol. 2, No. 2, Pp. 127-133, 2013.

[11] F. S. Rahayu, D. Budiyanto, And D. Palyama, 'Analisis Penerimaan E-Learning 
Menggunakan Technology Acceptance Model (Tam) (Studi Kasus: Universitas Atma Jaya Yogyakarta)', Jutei: Jurnal Terapan Teknologi Informasi, Vol. 1, No. 2, Pp. 85-95, 2017.

[12] L. Purwianti And K. Tio, 'Faktor-Faktor Yang Mempengaruhi Behavioural Intention', Jurnal Manajemen Maranatha, Vol. 17, No. 1, P. 15, 2017, Doi: 10.28932/Jmm.V17i1.415.

[13] S. Alharbi And S. Drew, 'Using The Technology Acceptance Model In Understanding Academics' Behavioural Intention To Use Learning Management Systems', International Journal Of Advanced Computer Science And Applications, Vol. 5, No. 1, 2014, Doi: 10.14569/Ijacsa.2014.050120.

[14] I. Ghozali And H. Latan, Partial Least Squares Konsep, Teknik Dan Aplikasi Menggunakan Program Smartpls 3.0 Untuk Penelitian Empiris, 2nd Ed. Semarang: Badan Penerbit Universitas Diponegoro Semarang, 2014.

[15] A. A. G. Al. Alfa, D. Rachmatin, And F. Agustina, 'Analisis Pengaruh Faktor Keputusan Konsumen Dengan Structural Equation Modeling Partial Least Square', Eurekamatika, Vol. 2, Pp. 59-71, 2017.

[16] J. F. Hair, C. M. Ringle, And M. Sarstedt, 'Pls-Sem: Indeed A Silver Bullet', Journal Of Marketing Theory And Practice, Vol. 19, No. 2, Pp. 139-152, 2011, Doi: 10.2753/Mtp1069-6679190202. 